\title{
The Impact of a Novel Apolipoprotein E and Amyloid- $\beta$ Protein Precursor-Interacting Protein on the Production of Amyloid- $\beta$
}

\author{
Paul C.R. Hopkins*, Ricardo Sáinz-Fuertes and Simon Lovestone \\ Kings College London, MRC Centre for Neurodegeneration Research, Institute of Psychiatry, \\ De Crespigny Park, London, UK
}

Handling Associate Editor: Toshiharu Suzuki

Accepted 4 April 2011

\begin{abstract}
Alzheimer's disease (AD) is characterized by disrupted metabolism of the amyloid- $\beta$ protein precursor (A $\beta P P)$ and deposition of a byproduct, the amyloid- $\beta$ (A $\beta$ ) peptide, into plaques. AD is also genetically linked to the gene for apolipoprotein $\mathrm{E}$ (apoE). We have identified a novel apoE-binding protein (TMCC2) that also forms a complex with A $\beta P P$. TMCC 2 is a neuronal, predominantly ER-localized, protein that co-migrated with A $\beta P P$ during native gel electrophoresis of rat brain extracts, and co-immunoprecipitated with A $\beta P P$ from transfected human cell lysates. TMCC2 bound apoE in an isoform-specific manner in vitro and co-immunoprecipitated with apoE from cell lysates. Co-expression of apoE and TMCC 2 stimulated $\mathrm{A} \beta$ production from the "Swedish" variant of A PPP (K595 M/N596L) by up to 1.5 -fold $(p<0.05)$, and also from the 99-amino acid C-terminal fragment of $\mathrm{A} \beta \mathrm{PP}(\mathrm{A} \beta \mathrm{PP}-\mathrm{C} 99)$ that is the direct precursor to $\mathrm{A} \beta$ by 1.5 - to 2 -fold $(p<0.0005)$, this effect was greater with apoE4 than apoE3 $(p=0.02)$; both apoE3 and apoE4 stimulated a greater increase in $\mathrm{A} \beta_{1-42}$ than $\mathrm{A} \beta_{1-40}$ production from $\mathrm{A} \beta \mathrm{PP}-\mathrm{C} 99$ in the presence of TMCC 2 . The interaction between TMCC 2 and apoE may therefore contribute to disrupted A $\beta P P$ metabolism and altered $\mathrm{A} \beta$ production, as observed in $\mathrm{AD}$.
\end{abstract}

Keywords: Alzheimer's disease, amyloid- $\beta$, amyloid- $\beta$ precursor protein, apolipoprotein E, TMCC2

\section{INTRODUCTION}

Late onset Alzheimer's disease (AD) is linked to common polymorphisms of the gene for apolipoprotein $\mathrm{E}$ (apoE). ApoE3, the most common isoform, contains a cysteine at position 112, and an arginine at position 158, whereas apoE4 contains arginines at both positions. The increased risk of $\mathrm{AD}$ associated with possession of the APOE $\varepsilon 4$ allele, first proposed in $1993[1,2]$, has been confirmed in numerous studies

\footnotetext{
*Correspondence to: Paul C.R. Hopkins, MRC Centre for Neurodegeneration Research, Institute of Psychiatry, Kings College London, De Crespigny Park, London, SE5 8AF. Tel.: +44 20 7848 0623; Fax: +44 207848 0632; E-mail: hopkins.dementin@ gmail.com.
}

since; this single point mutation is therefore proposed to be the single most common genetic risk factor for late onset $\mathrm{AD}[3]$.

Familial and late-onset $\mathrm{AD}$ are pathologically similar conditions distinguished from other neurodegenerative diseases by aberrant metabolism of the amyloid- $\beta$ protein precursor $(\mathrm{A} \beta \mathrm{PP})$ and accumulation of the amyloid- $\beta(A \beta)$ peptide that derives from $A \beta P P$ into fibrillar plaques. Familial AD (FAD) is genetically associated with mutations in the genes for $A \beta P P$, presenilin 1, or presenilin 2 [4-7]. The finding that the presenilins are essential components of the $\gamma$-secretase complex that catalyzes the final step in A $\beta$ PP proteolysis $[8,9]$ provided a molecular mechanism linking the role of these two genes in FAD. 
Production of $A \beta$ from $A \beta P P$ by $\gamma$-secretase requires the prior release of the A $\beta P P$ ectodomain by the $\beta$-secretase BACE $[10,11]$ which yields secreted $\mathrm{A} \beta \mathrm{PP}$ and a 99 amino-acid C-terminal fragment (A $\beta P P-C 99)$ that contains the $\mathrm{A} \beta$ and intracellular sequences of $A \beta P P$. Deposited fibrillar $A \beta$ is a product of $A \beta P P$ metabolism and its deposition is influenced both by the rates of the various proteolytic steps leading to its production and the cellular location in which they occur (reviewed in [12]).

A role for apoE in A $\beta P P$ metabolism was suggested following the observation that apoE-null mice expressing dominant negative forms of human A $\beta P P$ that lead to $\mathrm{AD}$ have a reduced development of fibrillar amyloid plaques [13-16]. Furthermore, an isoformspecific effect of human apoE on A $\beta P P$ metabolism was demonstrated by showing that mice expressing apoE4 develop fibrillar amyloid plaques sooner than those expressing apoE3 [17-20]. However, in contrast to the increased deposition of $A \beta$ seen in wild-type compared to apoE-null mice, in vitro studies have instead shown that apoE suppresses the conversion of A $\beta P P$ to $A \beta[21]$.

Several studies have demonstrated binding of apoE to $A \beta$ in vitro and proposed that this binding may drive amyloid deposition [2, 22, 23], however the existence of an apoE isoform-specific effect in this binding is uncertain, possibly in part due to difficulties in replicating in vivo conditions with respect to the lipidation status of apoE and $\mathrm{A} \beta$ conformation. Furthermore, expression of apoE is neither necessary nor sufficient to drive the deposition of fibrillar amyloid, as apoEnull mice regain the ability to deposit fibrillar amyloid if the mice are also null for clusterin [24], and mice overexpressing BACE have reduced fibrillar amyloid deposition in the presence of apoE [25]. In addition, it has been shown that in aged, but not young, mice apoE4 increases not only insoluble, but also soluble $\mathrm{A} \beta$ levels compared to apoE3 [17-19]. Thus, while a wealth of data indicates that apoE modulates the formation of amyloid plaques, and by implication A $\beta P P$ metabolism, the mechanism underlying the isoformspecific effect of apoE is unclear.

We have identified a novel protein, TMCC2, which exhibits an isoform-specific interaction with apoE, both in vitro and in cells. We found that TMCC2 forms a complex with $\mathrm{A} \beta \mathrm{PP}$ and interacts with apoE to increase production of $\mathrm{A} \beta$ from $\mathrm{A} \beta \mathrm{PP}-\mathrm{C} 99$, this effect being greater with apoE4 than apoE3. TMCC2 may therefore contribute to an isoform-specific effect of apoE on A $\beta P P$ metabolism.

\section{MATERIALS AND METHODS}

\section{cDNA constructs}

Human TMCC2 (Acc. No. AB007950, Kazusa, Chiba, Japan) was amplified by PCR and cloned into pcDNA3.1 (Invitrogen). A plasmid expressing dsRedER was obtained from Clontech, plasmids expressing apoE isoforms have been previously described [26]; plasmids expressing A $\beta P P 695$ and the Swedish variant thereof (K595 M/N596L, AßPP695 numbering) were obtained from C. Miller (Kings College, London). All transfections using full-length AßPP or AßPPswe used AßPP695. A plasmid expressing the 99 amino acid C-terminal fragment fused to EGFP with an additional Asp-Ala dipeptide after the signal peptide sequence as described [27] was made by cutting A $\beta P P 695$ fused to the $\mathrm{N}$-terminus of EGFP (a gift of C. Miller, Kings College, London) with Bgl II and EcoRI and ligation to a cassette consisting of the following oligonucleotides: GATCTA TGCTGCCCGGTTTGGCACTGCTCCTGCTGGCC GCCTGGACGGCTCGGGCGGATGCAGATGCAG, and AATTCTGCATCTGCATCCGCCCGAGCCGT CCAGGCGGCCAGCAGGAGCAGTGCCAAACCG GGCAGCATA.

\section{Antibodies}

Antibody 94: a recombinant TMCC2 fragment comprising residues 252 to 648 , was produced as described below and injected into rabbits at Harlan Teklad (UK). Antibody 94 was used at a concentration of $1: 1000$ in $5 \%$ milk, $150 \mathrm{mM} \mathrm{NaCl}, 50 \mathrm{mM}$ Tris.Cl pH 7.4. Rabbit polyclonal antibody A5137 directed against the final 20 amino acids of human AßPP was a gift of C. Miller (Kings College, London). Goat polyclonal anti-apoE was obtained from Calbiochem, and goat anti-presenilin-1 C-terminal fragment (C20) was obtained from Santa Cruz Biotechnologies. Mouse anti-Golgi $58 \mathrm{~K}$ and rabbit anti-BiP and mouse monoclonal antibody $22 \mathrm{C} 11$ against the A $\beta P P$ ectodomain were purchased from Sigma Aldrich. Antibody 4 G8 targeted to $A \beta$ residues 17-24 was purchased from Covance, and anti-A $\beta$ antibody WO-2 targeted to residues 4-10 from Millipore.

\section{Western blots}

Western blots were routinely developed using the ECL system (Amersham). 
Yeast-two-hybrid screen

A commissioned yeast-two-hybrid screen using apoE3 and apoE4 as baits and a human brain cDNA library as a source of targets used the MATCHMAKER system (Clontech, Palo Alto, USA).

\section{Production of recombinant TMCC2}

A cDNA encoding TMCC2 from amino acid $\mathrm{Met}^{79}$ to $\operatorname{Arg}^{640}$ (adjacent to the first predicted transmembrane region) was amplified by PCR and cloned into the pBADThio vector (Invitrogen); the $5^{\prime}$ primer contained an in-frame coding sequence for the FLAG epitope (DYKDDDDK). This resulted in a construct encoding a thioredoxin-TMCC2 $2^{79-640}$ fusion protein (trxA-TMCC2) in which the codons for the first exon of TMCC2 were replaced by codons for thioredoxin, followed by the FLAG sequence, TMCC $2^{79-640}$, and at the C-terminus, a six-His tag. Expression was induced by adding arabinose (final concentration, $0.2 \%$ ) to a log-phase culture of transformed Escherichia coli at $37^{\circ} \mathrm{C}$. Cell pellets were lysed in $6 \mathrm{M}$ guanidine- $\mathrm{HCl}$, $150 \mathrm{mM} \mathrm{NaCl}$, and $20 \mathrm{mM}$ Tris-Cl, pH 8.0, and cleared by centrifugation at $15,000 \mathrm{~g}$ for $1 \mathrm{~h}$. The supernatant was loaded onto a $\mathrm{Ni}^{2+}$-chelating sepharose column, and proteins were eluted with a gradient of $0-150 \mathrm{mM}$ imidazole in $6 \mathrm{M}$ guanidine- $\mathrm{HCl}, 150 \mathrm{mM} \mathrm{NaCl}$, and $20 \mathrm{mM}$ Tris-Cl, pH 8.0. After dialysis against $1.0 \mathrm{mM}$ $\mathrm{HCl}$, fractions containing trxA-TMCC2 were identified by SDS-PAGE and staining with Coomassie-blue, readjusted to $6 \mathrm{M}$ guanidine- $\mathrm{HCl}, 150 \mathrm{mM} \mathrm{NaCl}$, and $20 \mathrm{mM}$ Tris-Cl, $\mathrm{pH} 8.0$, and passed over a $\mathrm{Ni}^{2+}$-chelating column as described above. Fractions containing trxA-TMCC2 were dialyzed against $1 \mathrm{mM}$ $\mathrm{HCl}$ and lyophilized. trxA-TMCC2 was dissolved in $6.0 \mathrm{M}$ guanidine $\mathrm{HCl}, 1.0 \mathrm{M}$ L-arginine, $150 \mathrm{mM}$ $\mathrm{NaCl}, 200 \mathrm{mM}$ trimethylamine n-oxide, $40 \mathrm{mM}$ ammonium bicarbonate, and $10 \mathrm{mM}$ dithiothreitol. Proteins were refolded by rapid dilution with 10 volumes of 1.0 M L-arginine, $150 \mathrm{mM} \mathrm{NaCl}, 200 \mathrm{mM}$ trimethylamine n-oxide, $100 \mathrm{mM}$ ammonium bicarbonate, and $10 \mathrm{mM}$ dithiothreitol and dialyzed against $150 \mathrm{mM}$ $\mathrm{NaCl}, 100 \mathrm{mM}$ ammonium bicarbonate, and $100 \mathrm{mM}$ trimethylamine n-oxide. In vitro association of $T M C C 2^{79-640}-\operatorname{trxA}$
and apoE

The intrinsic fluorescence of trxA-TMCC2, apoE3, apoE4, and thioredoxin was measured with a Hitachi
F2000 fluorimeter. Proteins were excited at $295 \mathrm{~nm}$, and fluorescence emission was measured from 300 to $450 \mathrm{~nm}$. All protein concentrations were $1.0 \mu \mathrm{M}$, and all measurements were performed at $25^{\circ} \mathrm{C}$ in $150 \mathrm{mM} \mathrm{NaCl}, 100 \mathrm{mM}$ ammonium bicarbonate, and $100 \mathrm{mM}$ trimethylamine n-oxide after co-incubation for $1 \mathrm{~h}$. The change in total fluorescence at $342 \mathrm{~nm}$ on co-incubation is expressed as a percent of the sum of individual fluorescences in individual assays. Four independent assays using separately purified and prepared samples of trxA-TMCC2 were performed. Recombinant apoE3, apoE4 and thioredoxin were gifts of Yvonne Newhouse and Karl Weisgraber (Gladstone Institute of Neurological Disease, San Francisco, USA).

\section{Detection of TMCC2 in mouse brain by in situ}

The image showing TMCC2 expression in mouse brain was obtained from the Allen Mouse Brain Atlas [Internet]. Seattle (WA): Allen Institute for Brain Science. (C2009. Available from: http://mouse.brainmap.org.

\section{Sucrose-gradient fractionation of mouse} and rat brain

One whole adult mouse brain was homogenized by 50 strokes of a dounce homogenizer in $50 \mathrm{mM}$ imidazole. $\mathrm{HCl}, \mathrm{pH} 7.0,0.25 \mathrm{M}$ sucrose, $1 \mathrm{mM}$ EDTA and protease inhibitors (Cømplete, Boehringer Mannheim); $10 \mathrm{ml}$ was used for a mouse brain and $50 \mathrm{ml}$ for a rat brain. The homogenate was centrifuged at $600 \mathrm{~g}$ for $10 \mathrm{~min}$. and the supernatant loaded onto a $1.9 \mathrm{M}$ to $0.25 \mathrm{M}$ sucrose gradient in the above buffer and centrifuged for $95,000 \mathrm{~g}$ for $18 \mathrm{~h}$. $1 \mathrm{ml}$ fractions were collected from the bottom of the tube and either analyzed by western blot or stored at $-80^{\circ} \mathrm{C}$.

\section{Primary cortical neurons}

Primary rat cortical neurons were obtained from E18 rat embryos and cultured on either culture plates or glass coverslips (for indirect immunofluorescence staining) coated with poly-d-lysine in Neurobasal medium and B27 supplement (Invitrogen) containing 100 units $/ \mathrm{ml}$ penicillin, $100 \mathrm{mg} / \mathrm{ml}$ streptomycin, and $2 \mathrm{mM}$ glutamine. 
Two-dimensional blue-native/SDS PAGE of rat brain extracts-

A TMCC2-enriched rat brain fraction was prepared as follows. The TMCC2-containing sucrose-gradient fraction prepared as above was diluted 10-fold with $50 \mathrm{mM}$ imidazole. $\mathrm{HCl}, \mathrm{pH} 7.0,0.25 \mathrm{M}$ sucrose, $1 \mathrm{mM}$ EDTA and protease inhibitors (Cømplete, Boehringer Mannheim) and centrifuged at $1,500 \mathrm{~g}$ for $5 \mathrm{~min}$, TMCC2 was enriched in the pellet. The pellet was resuspended in $1 \%$ Triton $\mathrm{X}-100,1 \% \mathrm{NP}-40$ and $1 \%$ Coomassie blue R-250 in $50 \mathrm{mM}$ imidazole. $\mathrm{HCl} \mathrm{pH}$ 7.0 and centrifuged at $100,000 \mathrm{~g}$ for $20 \mathrm{~min}$ to remove insoluble material. The supernatant was fractionated by electrophoresis on a 4-13\% acrylamide gradient gel as described [28]. Gel strips were excised and incubated in $100 \mathrm{mM}$ Tris.Cl pH 6.8, 1\% SDS, $10 \mathrm{mM}$ DTT for $30 \mathrm{~min}$ and inserted between the plates of a previously poured SDS-PAGE gel without a stacking gel. A stacking gel was then poured around and under the strip and allowed to polymerize. The gel was run and the proteins transferred to polyvinyl difluoride membranes (Millipore) and analyzed by western blot in a conventional manner. Progenesis Samespots software was used to align blots double-probed for TMCC2 and presenilin, using the edges of overexposed blot as anchor points.

\section{Co-immunoprecipitations}

For co-immunoprecipitation of TMCC 2 with A $\beta P P$, SHSY5Y cells were transfected with plasmids driving expression of TMCC2 tagged at the Cterminus with the FLAG sequence (DYKDDDDK) and $A \beta P P^{695}$ using Lipofectamine2000 (Invitrogen); $24 \mathrm{~h}$ after transfection cells were lysed in phosphatebuffered saline, $1 \%$ Triton $\mathrm{X}-100$, protease inhibitors (Cømplete, Boehringer Mannheim) and phosphatase inhibitors (10 mM NaF, $4 \mathrm{mM} \beta$-glycerophosphate). Lysates were centrifuged at 100,000 g to remove insoluble material and incubated overnight with agarose beads coupled to the M2 anti-FLAG antibody (Sigma Aldrich). The beads were washed 6 times in the above buffer over a period of $2 \mathrm{~h}$. Bound proteins were eluted with SDS-containing gel loading buffer, separated by SDS-PAGE and transferred to nitrocellulose for analysis by western blot. TMCC 2 was detected using the rabbit antibody 94 directed raised against recombinant TMCC2, AßPP was detected using antibody A5137.

For co-immunoprecipitation with apoE, FLAGtagged TMCC2 and apoE were co-transfected as above, $24 \mathrm{~h}$ after transfection cells were washed 3 times with PBS and incubated with $0.6 \mathrm{mM}$ dithiobis (succinimidyl propionate) (Pierce) in PBS for $10 \mathrm{~min}$ to stabilize protein complexes. Cells were washed with PBS 3 times and lysed in PBS containing 1\% Triton $\mathrm{X}-100,1 \% \mathrm{NP} 40,100 \mathrm{mM}$ Tris. $\mathrm{Cl} \mathrm{pH} 7.4$ and protease inhibitors (Cømplete, Boehringer Mannheim) and cleared by centrifugation at $100,000 \mathrm{~g}$ for $20 \mathrm{~min}$. The supernantant was incubated with M2-agarose (Sigma) overnight, the beads washed 6 times with the above buffer over $2 \mathrm{~h}$ and captured proteins eluted with Laemmli gel loading buffer containing $100 \mathrm{mM}$ DTT at $95^{\circ} \mathrm{C}$ for $10 \mathrm{~min}$.

For co-immunoprecipitation of TMCC 2 with A $\beta$ PPC99-EGFP, plasmids for the expression of both proteins were transfected into SHSY5Y cells as above, captured using antibody 4 G8 coupled to protein A/G agarose, and treated as above.

\section{Immunocytochemistry}

Co-localization of TMCC 2 with A $\beta$ PP: Primary rat cortical neurons were fixed with cold methanol and blocked with $50 \mathrm{mM}$ Tris. $\mathrm{Cl} \mathrm{pH} \mathrm{7.4,} 150 \mathrm{mM} \mathrm{NaCl}$, $0.1 \%$ Triton X-100, $1 \%$ casein and probed with a $1: 500$ dilution of antibody 94 or pre-immune serum, and a $1: 100$ dilution of antibody 4 G8 or 6 E10 in the same buffer. Bound primary antibody was detected using Alexa 543-conjugated goat anti-rabbit antibody and using Alexa 488-conjugated goat anti-mouse (Invitrogen). Images were captured using a Zeiss510 meta confocal microscope. Co-localization of TMCC2 with dsRedER: to demonstrate co-localization of TMCC2 and dsRedER in the endoplasmic reticulum, plasmids driving expression of these proteins were co-transfected using Lipofectamine2000 as indicated above. After $24 \mathrm{~h}$ cells were fixed with $4 \%$ paraformaldehyde, and treated with antibody 94 as above, with bound antibody 94 being detected with Alexa-488-conjugated goat anti-rabbit (Invitrogen).

\section{Assessment of the impact of TMCC2 on $A \beta$ production}

A $\beta$ production from SHSY5Y cells was assayed using ELISA kits purchased from Millipore and used as directed by the manufacturer. SHSY5Y cells were routinely cultured in $42 \%$ F12 media (Gibco), $42 \%$ EMEM media (Sigma), and $15 \%$ bovine calf serum, supplemented with glutamate, non-essential amino acids and sodium pyruvate. SHSY5Y cells were seeded into 6-well dishes and cultured for $48 \mathrm{~h}$ before being transfected with the constructs indicated. Transfections 
were achieved using Lipfectamine2000 (Invitrogen), as directed by the manufacturer, using $2 \mu$ l Lipofectamine 2000 per $1 \mu \mathrm{g}$ of plasmid DNA per well, where necessary, amounts of DNA added were adjusted to yield equivalent expression levels, empty pcDNA3.1 used to normalize the amount of DNA in each transfection. Transfections were allowed to proceed for $4 \mathrm{~h}$, after which the transfection mixture was replaced with fresh Optimem; media and cells were harvested after $36 \mathrm{~h}$.

Denaturing urea/SDS-PAGE gel electrophoresis analysis of $A \beta$ used the method described by Wiltfang et al. [29]. Briefly, A $\beta$ was captured by overnight incubation of culture media with antibody $4 \mathrm{G} 8$ bound to protein $\mathrm{A} / \mathrm{G}$ agarose. The beads were washed 6 times with PBS, $1 \%$ Triton-X-100 containing protease inhibitors (Complete, Boehringer Mannheim); $A \beta$ was eluted by heating in gel loading buffer and separated and detected by western blot using antibody WO-2 as described [29]. A $\beta$ peptides used as standards were purchased from California Peptide Research, Inc. In this gel system, longer species of $A \beta$ run ahead of shorter ones.

\section{RESULTS}

An isoform-specific association of apoE with TMCC2, initially suggested by a yeast-two-hybrid screen using apoE3 and apoE4 as baits and a human brain cDNA library as a source of targets (Fig. 1A) was confirmed in vitro by comparing the intrinsic tryptophan fluorescence of recombinant apoE and a recombinant TMCC2-thioredoxin fusion protein (Fig. 1B) when incubated alone or together. The combined fluorescence of apoE3 and TMCC2-thioredoxin, but not apoE4 and TMCC2-thioredoxin, increased by $15 \%$ when co-incubated (Fig. 1C). As the TMCC2 portion of this fusion protein does not contain tryptophans, the increase in fluorescence may be attributed to a change in the local environment of one or more of the 7 tryptophans in apoE on binding of apoE3, but not apoE4, to TMCC2. That this binding may also occur in cells was supported by experiments showing coimmunoprecipitation of both apoE3 and apoE4 with TMCC2 from transfected cell lysates (Fig. 1D).

TMCC2 is a novel, evolutionarily conserved, 709 amino-acid protein; the human mouse and rat TMCC2 homologues (Unigene codes Hs.6360, Mm.273785 and Rn.106120, respectively) are over $90 \%$ identical in amino acid sequence. These proteins are predicted to possess two closely located transmembrane domains

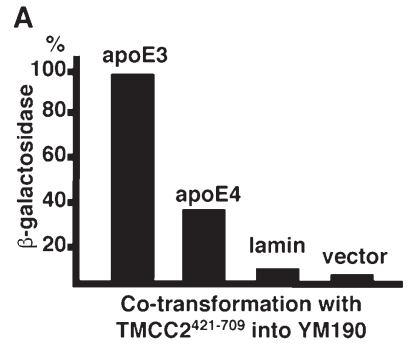

B
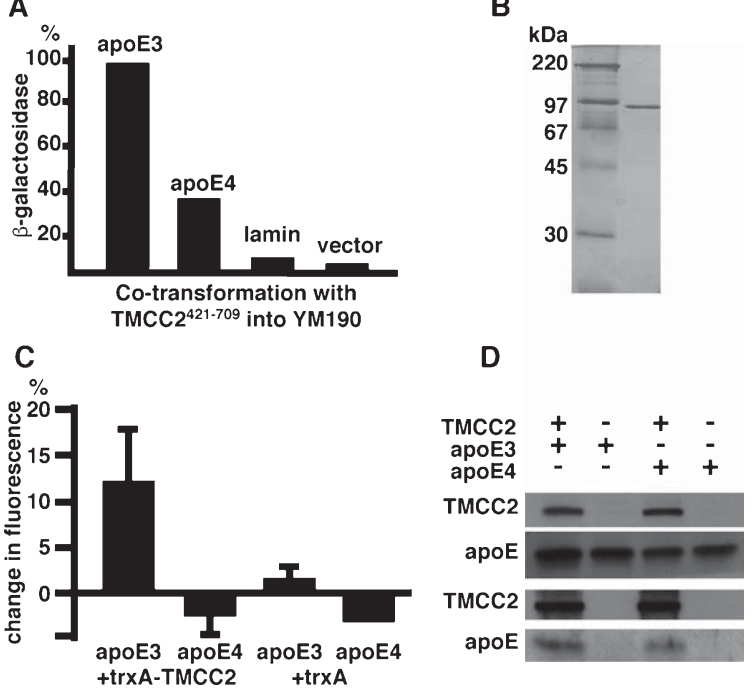

Fig. 1. TMCC2 forms complexes with apoE. A) Binding of TMCC2 and apoE in a yeast-two-hybrid assay. Relative $\beta$-galactosidase activity in yeast co-transformed with apoE3 or apoE4 or lamin fused to the DNA-binding domain, and TMCC2 $221-709$ fused to the activation domain of Gal4, respectively. B) Coomassie-blue stained SDS-PAGE gel showing molecular weight markers (left lane) and purified recombinant TMCC2-trxA fusion protein (right lane). C) Binding of apoE and TMCC2- trxA in vitro. Columns represent the percent difference in fluorescence emission at $342 \mathrm{~nm}$ of the co-incubated proteins compared to the sum of their individual values; co-incubation of apoE3 but not apoE4 with a TMCC2thioredoxin fusion protein (trxA-TMCC2), but not thioredoxin alone (trxA), results in an increased fluorescence relative to the sum of individual fluorescences. The data presented are the mean results obtained from four experiments using independent preparations of TMCC2-trxA, error bars represent the standard deviation. D) Coimmunoprecipitation of TMCC2 and apoE. FLAG-tagged TMCC2 and apoE were expressed in SHSY5Y cells in the combinations indicated. Complexes were stabilized and captured using the M2 anti-FLAG antibody; apoE was captured only in complexes prepared from co-transfected cells.

near the $\mathrm{C}$-terminus and two coiled-coil domains but no leader peptide, suggesting that they are intracellular multipass transmembrane proteins. TMCC2 does not, however, have sufficient similarity to studied proteins for sequence analysis to predict its function.

Within the brain, TMCC2 is most likely a neuronal ER membrane protein. TMCC2 mRNA is widely expressed in the neurons of adult mice as detected by in situ (Fig. 2A). Antibody 94, developed against recombinant TMCC2, detected TMCC2 as a $\sim 100 \mathrm{kDa}$ band in rat primary cortical neurons (Fig. 2B, lane 1) and transfected SHSY5Y cells (Fig. 2B, lane 3) by western blot, but did not obviously detect TMCC2 in untransfected SHSY5Y cells (Fig. 2B, lane 2); the same band was detected with other antibodies targeted to TMCC2 (not shown), 
A
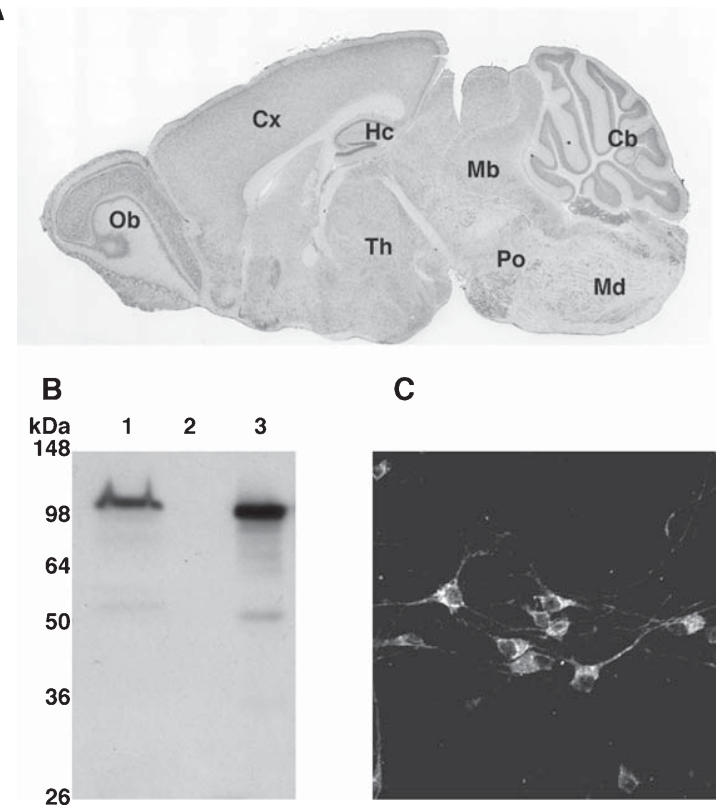

C

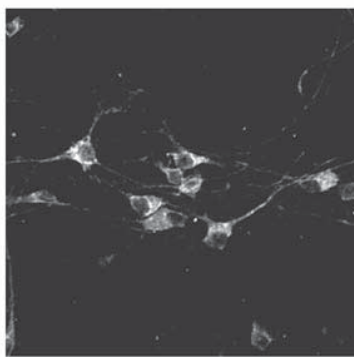

Fig. 2. Expression of TMCC2 in the brain and primary neurons. A) TMCC2 is widely expressed in mouse neurons as determined by in situ (data from the Allen Brain Atlas, http://mouse.brainmap.org Verified); Ob, olfactory bulb; Cx, cortex; Hc, hippocampal formation; Th, thalamus; $\mathrm{Mb}$, midbrain; $\mathrm{Po}$, pons; $\mathrm{Md}$, medulla; $\mathrm{Cb}$ cerebellum. B) Specificity of antibody 94 and detection of TMCC2 in primary rat neurons by western blot. Proteins from primary cortical neurons (1), sham-transfected SHSY5Y cells (2), and SHSY5Y cells transfected with human TMCC2 (3), were separated on a $10 \%$ acrylamide SDS-PAGE gel; TMCC2 was detected by western blot using antibody 94 as described in materials and methods. C) Visualization of TMCC2 in the cell body and processes of methanol-fixed primary rat cortical neurons by indirect immunofluorescence using antibody 94 detected using Alexa543-conjugated goat anti-rabbit secondary.

but as antibody 94 showed greatest specificity it was used in subsequent experiments. An additional $\sim 50 \mathrm{kDa}$ band was weakly detected in both primary neurons and transfected cells, which may represent a minor post-translationally processed form. Indirect immunofluorescence of primary neurons using the same antibody showed that TMCC2 was distributed in the cell body and processes (Fig. 2C). TMCC2 sedimented to the ER-containing sucrose gradient fraction of mouse brain extracts, which also contained apoE (Fig. 3A); transfected human TMCC2 localized to the endoplasmic reticulum in human cells (Fig. 3B). Taken together, the distributed localization of TMCC2 in primary neurons, its sedimentation to the ER-containing fraction of sucrose gradients, and its co-localization with DsRedER in transfected cells indicate that TMCC2 is a protein that mostly localizes to the early secretory pathway.
Apart from apoE, the best-established genetic risk factors for $\mathrm{AD}$ are $\mathrm{A} \beta \mathrm{PP}$ and the presenilins. We therefore analyzed two-dimensional blue-native/SDSPAGE gels of rat brain ER fractions for TMCC2, A $\beta P P$ and presenilin 1, and found that TMCC2 co-migrated with $\mathrm{A} \beta P P$ in these brain extracts, but not with presenilin 1 (Figs. 4A and B). Figure 4A1 to A3 are the same blot that has been probed first with rabbit anti-A $\beta P P$, developed, washed and then re-probed with rabbit antiTMCC 2 . Some of the first (rabbit anti-A $\beta P P$ ) primary has remained on the blot and is detected again when the blot is developed after re-incubation with the rabbit anti-TMCC2 antibody 94, to yield the result shown in Fig. 4A2 and 4A3. The lower exposure of this reprobed blot, shown in Fig. 4A2, shows that A $\beta P P$ and TMCC2 have migrated to the same position in the native (horizontal) dimension since both the leading and trailing edges of the spots detected by the antiAßPP and anti-TMCC2 antibodies are aligned. By coincidence, A $\beta P P$ and TMCC 2 also migrate similarly on SDS-PAGE, allowing the spots to be visualized in the same place.

Figure 4A3 is a longer exposure of the same blot as shown in Fig. 4A2, and shows the same pattern for TMCC2 as that shown in Fig. 4B1, which was probed only with anti-TMCC2, thus controlling for any artifacts caused by the double-probing of blot A.

The blot shown in Fig. 4B1 was probed first with the rabbit anti-TMCC2 antibody 94, after developing it was re-probed with goat anti-presenilin $1 \mathrm{C}$-terminus, to yield the blot shown in Fig. 4B3. Since the antigoat secondary antibody did not detect any remaining rabbit anti-TMCC2 primary, and to better compare the result of this double-probing with that for $\mathrm{A} \beta \mathrm{PP}$ and TMCC2 we created a merged image using "Progenesis SameSpots" software (Fig. 4B2), which showed that the putative TMCC2:A $\beta P P$ complex migrated ahead of the $\sim 400 \mathrm{kDa}$ presenilin 1 complex [30, 31 , suggesting that $\mathrm{A} \beta \mathrm{PP}$ and TMCC2 form a complex that is $200-300 \mathrm{kDa}$ in size. The existence of a TMCC2:A $\beta P P$ complex was further supported by co-immunoprecipitation assays, where A $\beta P P$ was immunoprecipitated by the M2 anti-FLAG tag antibody only from cells also expressing FLAG-tagged TMCC2 (Fig. 4C). A more selective, and reciprocal, immunoprecipitation from cells transfected with AßPP-C99 where immune complexes were captured using the anti-A $\beta P P$ antibody $4 \mathrm{G} 8$, indicated that TMCC2 interacts with the C-terminal region of A $\beta P P$ (Fig. 4D); immunoprecipitation of TMCC2 using anti-A $\beta P$ antibodies from cells co-transfected with full-length $\mathrm{A} \beta \mathrm{PP}$ was also observed (not shown). 


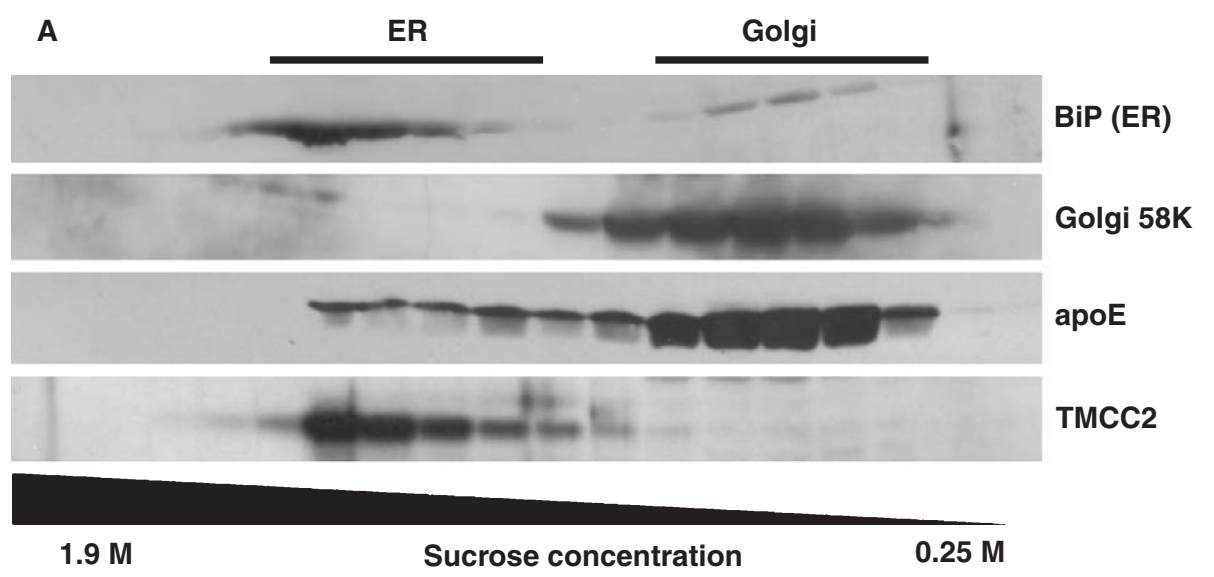

B

a

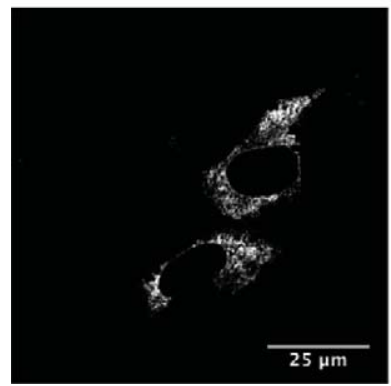

b

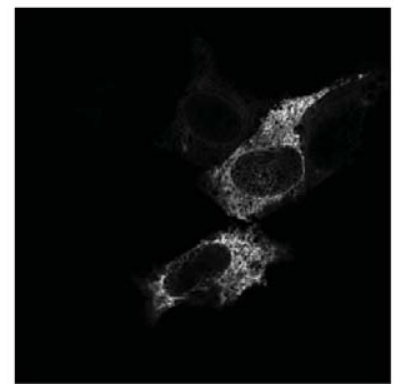

C

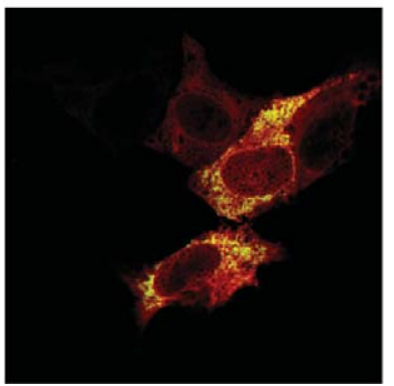

Fig. 3. TMCC2 is localizes predominantly to the ER. A) Co-sedimentation of TMCC2 and apoE with ER markers in sucrose density-fractionated brain extracts. Brain extracts were prepared as in materials and methods and $1 \mathrm{ml}$ fractions collected from the bottom of a $50 \mathrm{ml}$ sucrose gradient. The proteins in alternate fractions were separated by a $10 \%$ acrylamide SDS-PAGE gel and analyzed by western blot for the antigens indicated. B) Single confocal sections of cells transfected with TMCC2 and dsRedER showing that TMCC2 localizes to the ER in transfected SHSY5Y cells. TMCC2 detected by indirect immunofluorescence using antibody 94 is shown in (a); dsRedER is shown in (b), and a merged image in (c).

Partial co-localization of TMCC2 with A $3 P$ Pas observed in primary neurons, where TMCC2 was detected with antibody 94 and A $\beta P P$ with antibody $4 \mathrm{G} 8$, which will detect $\mathrm{A} \beta \mathrm{PP}$, its C-terminal fragments, and $\mathrm{A} \beta$; pre-immune serum and monoclonal antibody $6 \mathrm{E} 10$, which does not bind rat $\mathrm{A} \beta \mathrm{PP}$, were included as negative controls (Fig. 4E).

ApoE is expressed in adult mouse and human neurons following excitotoxic stress [32, 33, 34], and in primary human neurons [35]. However, expression of apoE has yet to be confirmed in primary rodent neurons. We therefore investigated the impact of coexpressing TMCC 2 and apoE on A $\beta P P$ metabolism in the human hippocampal neuron-derived cell line SHSY5Y, which expresses A $\beta P P$ isoforms 695, 751, and 770 , as determined by western blot and analysis of mRNA [36, 37]. While we propose that TMCC2 is primarily an ER protein, we did not observe retention of $\mathrm{A} \beta \mathrm{PP}$ in the ER on co-expression of TMCC2 with either A $\beta P P$ or A $\beta P P-C 99$ (not shown). However, by measuring the production of $\mathrm{A} \beta$ we found that co-transfection of either apoE isoform with TMCC2 was associated with a small effect on the production of $A \beta_{1-40}$, but not $A \beta_{1-42}$, when compared to apoE or TMCC2 alone (Fig. 5A and B). In contrast, co-expression of apoE and TMCC2 with the "Swedish" pathological variant of A $\beta P P$ (A $\beta P P s w e$, K595 M/N596L) showed a significant effect of both apoE isoforms and TMCC2 on $\mathrm{A} \beta$ secretion (Fig. $5 \mathrm{C}$ and D).

A $\beta$ PPswe generates excess A $\beta$ PP-C99, we therefore examined the effect of TMCC2 and apoE on $\mathrm{A} \beta$ generation directly from A $\beta P$-C99 which previous reports indicate is ordinarily processed to $A \beta$ by $\gamma$-secretase in cultured cells in the same manner as fulllength A $\beta P P$ [27]. We found a similar effect of TMCC2 and apoE on cell-associated $A \beta$ as was shown for $A \beta$ secretion using A $\beta P P$ swe (Fig. 6A); likewise, analysis of secreted $A \beta$ by immunoprecipitation and urea/SDSPAGE showed that TMCC 2 and apoE cooperated to 

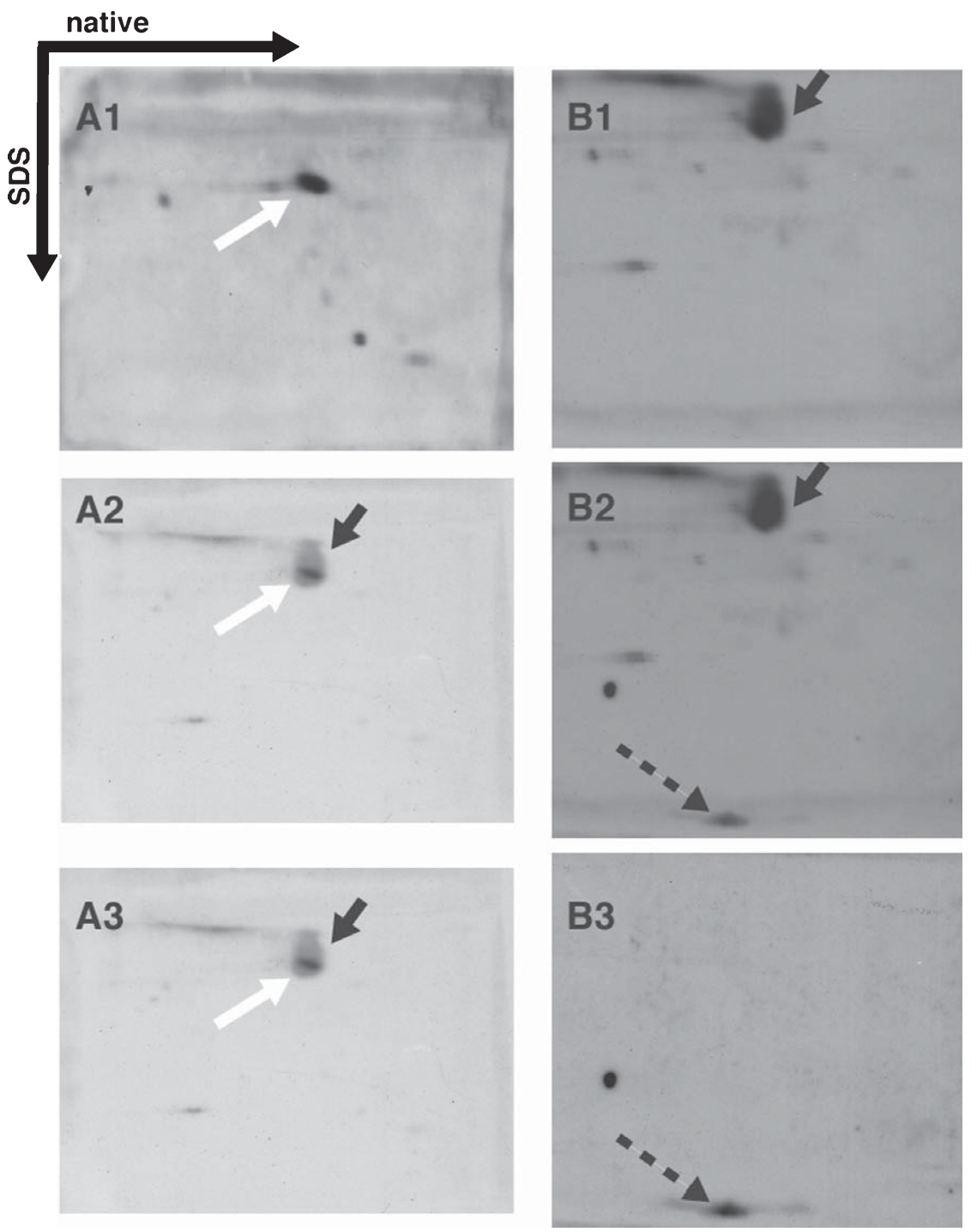

Fig. 4. TMCC2 forms a complex with A $\beta P P$. Western blot analysis of 2-dimensional blue-native/SDS-PAGE gels shows co-migration of TMCC2 with A $\beta P P$ but not presenilin 1. Rat brain ER extracts were separated on 2-dimensional blue-native/SDS-PAGE gels and probed first for either $\mathrm{A} \beta \mathrm{PP}(\mathrm{A} 1$ ) or TMCC2 (B1). Blot A1 was then re-probed for TMCC2 to give blot A2, which showed co-migration of TMCC2 (black arrow) and A $\beta P P$ (white arrow). Image A3 is a longer exposure of blot A2. Blot B1 was re-probed for presenilin to give blot B3, which showed that TMCC2 (black arrow) did not co-migrate with the presenilin 1 complex (dashed arrow), as shown in the merged image (B2). AßPP was detected using the rabbit antibody A5137, TMCC2 with the rabbit antibody 94, and presenilin C-terminal fragment with the goat antibody C20. C) Co-immunoprecipitation of A $\beta P P$ and TMCC2. Plasmids for the expression of A $\beta P P$ and FLAG-tagged TMCC2 were co-transfected and lysates prepared after $24 \mathrm{~h}$. Immune complexes were captured with M2 anti-FLAG conjugated agarose, separated by SDS-PAGE, transferred to nitrocellulose and developed using the rabbit anti-A $\beta$ PP antibody A5137 or the rabbit anti-TMCC2 antibody 94 . A $\beta P P$ was captured only from lysates prepared from co-transfected cells. D) Co-immunoprecipitation of TMCC2 and A $\beta \mathrm{PP}-\mathrm{C} 99$. Plasmids for the expression of A $\beta \mathrm{PP}-\mathrm{C} 99$ and TMCC 2 were co-transfected as indicated and lysates prepared after $24 \mathrm{~h}$. Complexes were captured using protein A/G beads coupled to antibody $4 \mathrm{G} 8$ targeted to the $\mathrm{A} \beta$ sequence of $\mathrm{A} \beta \mathrm{PP}$, separated by SDS-PAGE, transferred to nitrocellulose and western blots developed using the rabbit anti-A $\beta P P$ antibody A5137 or the rabbit anti-TMCC2 antibody 94. TMCC2 was only captured from cells co-transfected with AßPP-C 99. E) Partial co-localization of A $\beta P$ and TMCC2 in primary rat cortical neurons. Neurons were incubated with either rabbit anti-TMCC2 antibody 94 or pre-immune serum from the same rabbit, and either mouse monoclonal anti-A $\beta P P$ antibodies $4 \mathrm{G} 8$ or 6E10, as indicated. Antibody $4 \mathrm{G} 8$ recognizes both human and rat $\mathrm{A} \beta \mathrm{PP}$, whereas antibody $6 \mathrm{E} 10$ does not recognize rat $\mathrm{A} \beta \mathrm{PP}$, and thus serves as a control. All samples were incubated with Alexa 543-conjugated goat anti-rabbit and Alexa 488-conjugated goat anti-mouse to detect bound antibodies. All images are single confocal sections captured during the same session under identical conditions with a Zeiss510 meta confocal microscope, and processed with ImageJ software. 
C

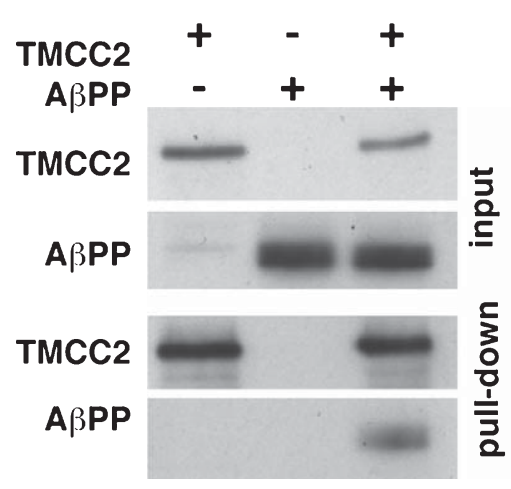

D

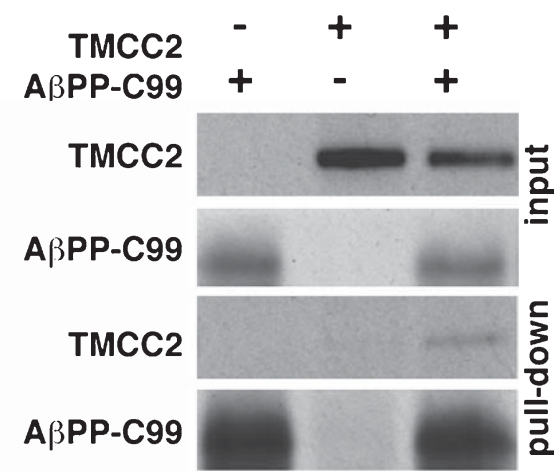

E TMCC2
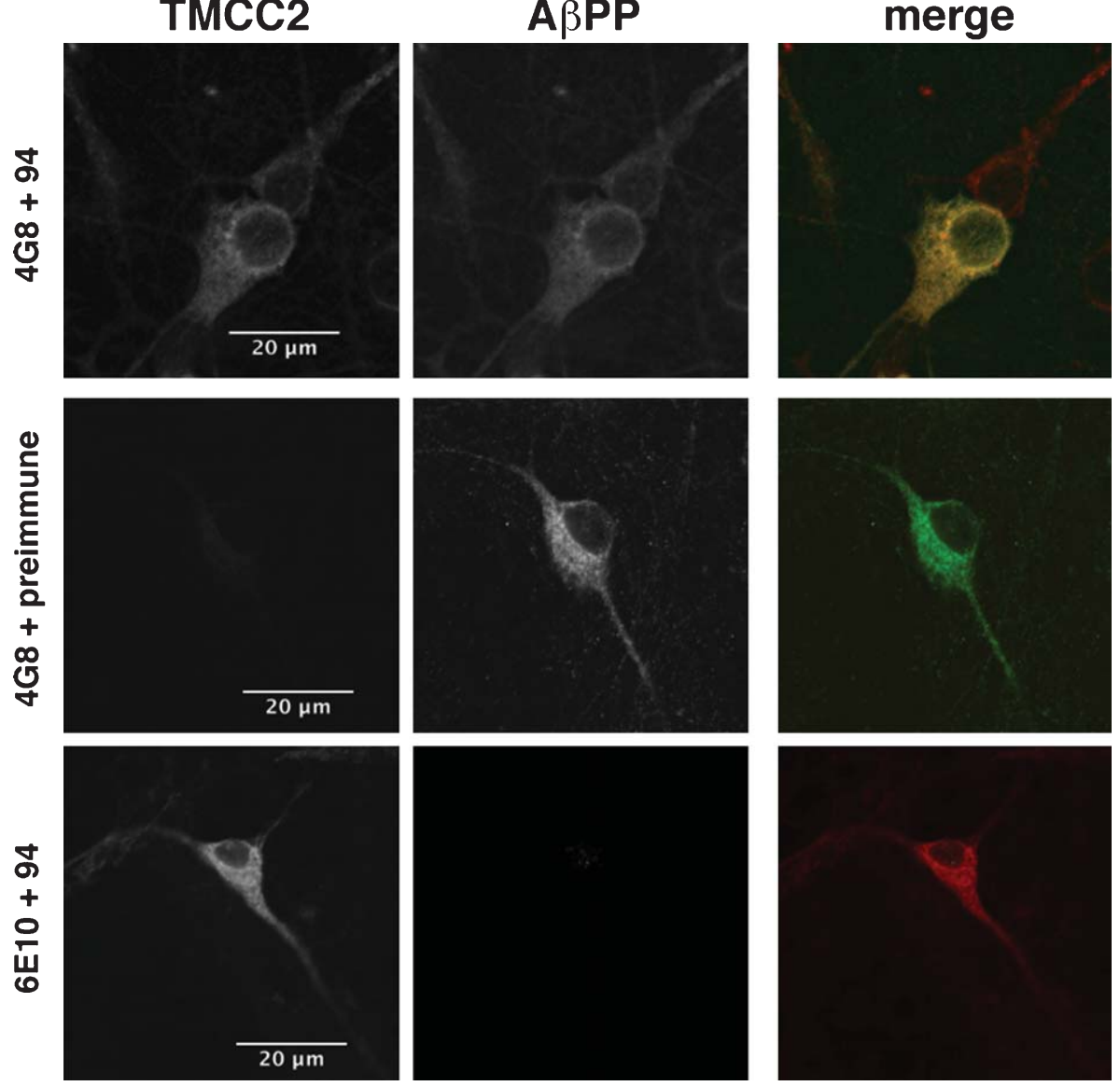

Fig. 4. (Continued)

increase the secretion of all major forms of $A \beta$ (Fig. 6B). Quantitation of secreted $A \beta_{1-40}$ and $A \beta_{1-42}$ showed a small trend for an increase in the amount of $\mathrm{A} \beta$ produced when A $\beta$ PP-C99 was co-expressed with apoE, but not an apoE isoform-specific effect, or an effect of TMCC2 alone; however, co-expression of apoE and TMCC2 markedly increased the production of $A \beta$ (Fig. 6C). Statistical analysis of these data using ANOVA with Dunnett's post-comparison test showed that a significant increase in the production of both $A \beta_{1-40}$ and $A \beta_{1-42}(p<0.0005)$ had occurred. In addition, a significant apoE isoform-specific effect 

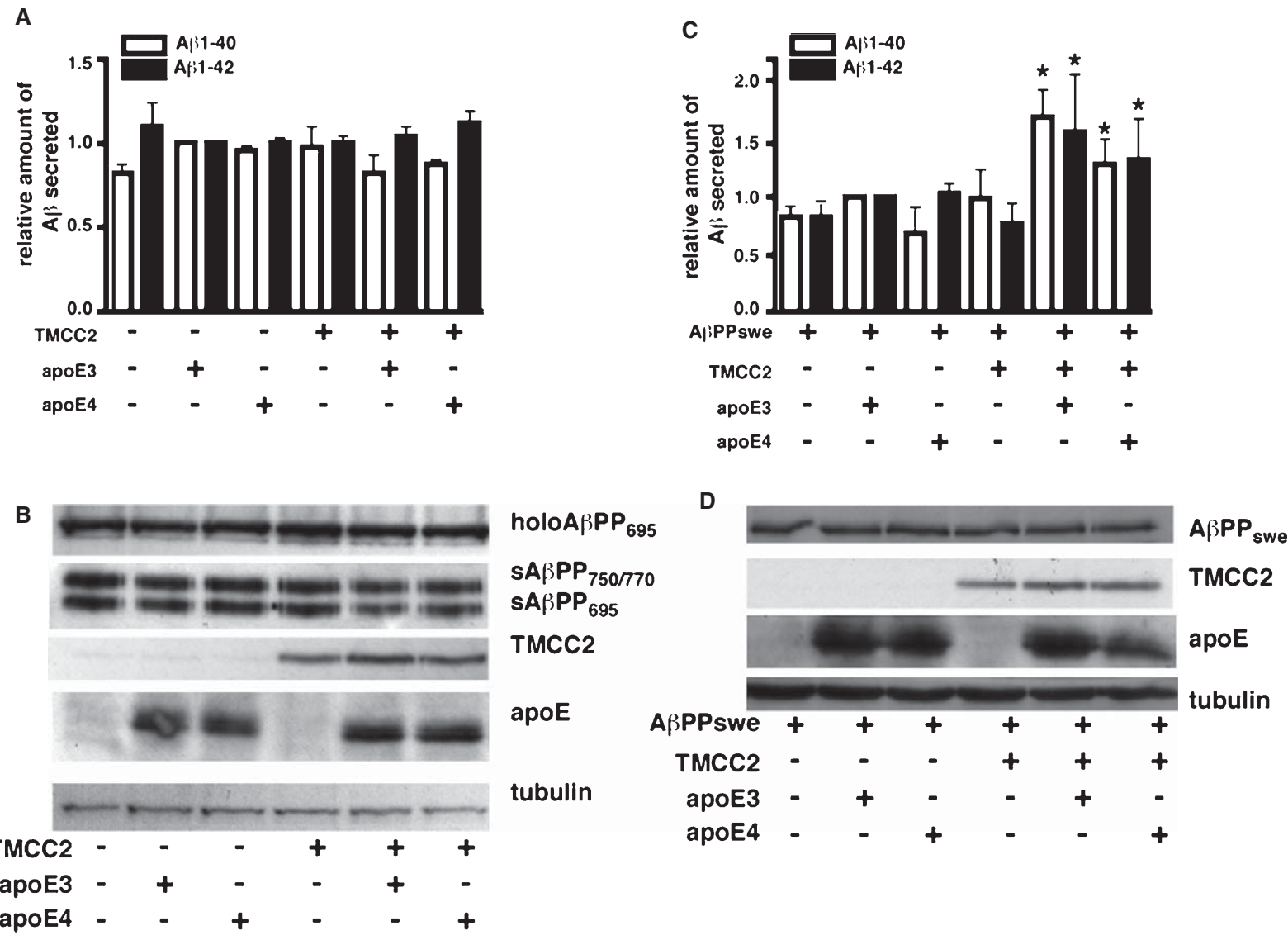

Fig. 5. ApoE and TMCC2 interact to modify A $\beta$ production from A $\beta P P$ swe. A) Relative to single transfections, co-transfection of SHSY5Y cells expressing A $\beta P P$ with apoE3 or apoE4 and TMCC2 partially suppressed the production of $\mathrm{A} \beta_{1-40}$ but not $\mathrm{A} \beta_{1-42}, P=0.09$, and $P=0.06$ for apoE3 and apoE4, respectively (Student's T-test). B) Lack of significant effect of apoE and TMCC2 on secreted A $\beta P P(s A \beta P P)$ as assessed by SDS-PAGE and immunoblot analysis for TMCC2, holoA $\beta P P$, or apoE in cell lysates, or sA $\beta P P$ in the media, of A $\beta P P-e x p r e s s i n g ~ S H S Y 5 Y$ cells expressing the proteins indicated. A blot for tubulin is included as a loading control. C) TMCC2 and apoE significantly increase A $\beta$ production from $A \beta P P$ swe. One-way ANOVA applied to the data for $A \beta_{1-40}$ and $A \beta_{1-42}$ separately showed a significant increase in $A \beta$ production $(P<0.05)$ on co-expression of TMCC2 and apoE, indicated by $* \mathrm{D})$ Representative western blots showing no significant effect of the expression of TMCC2 and apoE on the levels of AßPPswe. For (A) and (C), columns show mean values \pm SEM obtained from 5 and 3 independent experiments, respectively. To better visualize the relative impact of apoE and TMCC 2 on the production of each respective peptide, $\mathrm{A} \beta_{1-40}$ and $\mathrm{A} \beta_{1-42}$ levels were independently normalized to that where only apoE3 is expressed, since apoE is abundant in the brain, and apoE3 represents the most common isoform of apoE.

was observed, with more $\mathrm{A} \beta_{1-40}$ being produced when TMCC2 was co-expressed with apoE4 compared to apoE3 ( $p=0.02$, Student's T-test, Fig. 6C). More $A \beta_{1-42}$ than $A \beta_{1-40}$ was produced for both apoE3 and apoE4 (fold increases of $1.3 \pm 0.08$ versus $1.7 \pm 0.19$ and $1.98 \pm 0.24$ versus $1.51 \pm 0.08$, respectively), though these effects did not reach statistical significance; comparison of the amount of $A \beta_{1-40}$ and $\mathrm{A} \beta_{1-42}$ secreted on co-expression of TMCC2 with apoE4 showed $p=0.01$, whereas the difference in $A \beta_{1-40}$ and $A \beta_{1-42}$ produced on co-expression with apoE3 is $p=0.08$ (Student's T-test for both). These effects were not accompanied by significant alterations in the overall steady-state levels of A $\beta P P-$ C99 (Fig. 6D).

\section{DISCUSSION}

We have identified a novel protein that mediates a cellular interaction between apoE and A $\beta P P$. Our findings characterize TMCC2 as a neuronal protein that forms complexes with $\mathrm{A} \beta \mathrm{PP}$ in rat brain extracts and in transfected human cells. We found that TMCC2 modifies the production of $A \beta$ from $A \beta P P$ swe and AßPP-C99 in a human cell line when co-expressed with apoE where TMCC2 likely, directly or indirectly, 


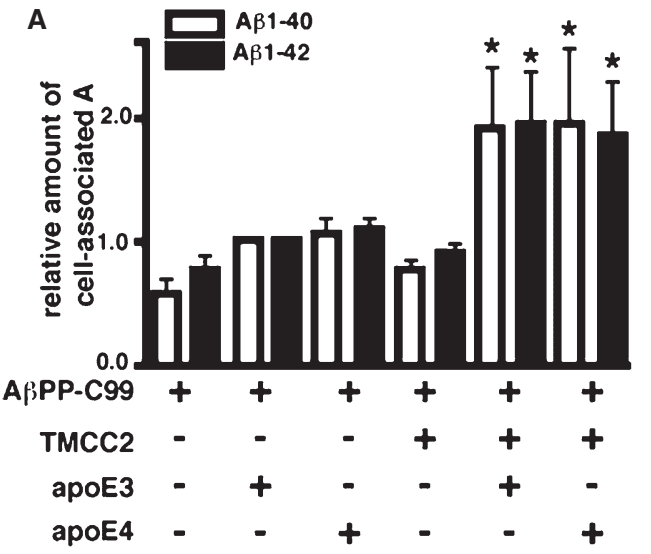

B

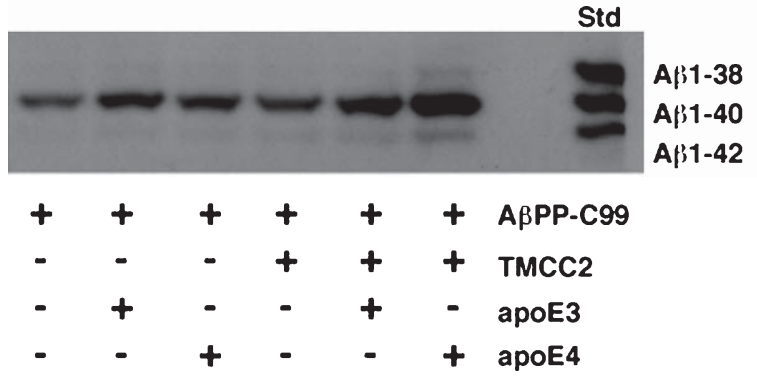

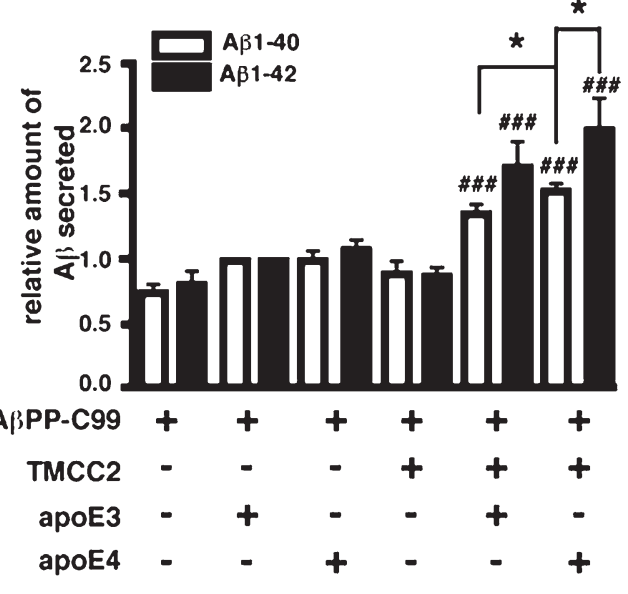

D
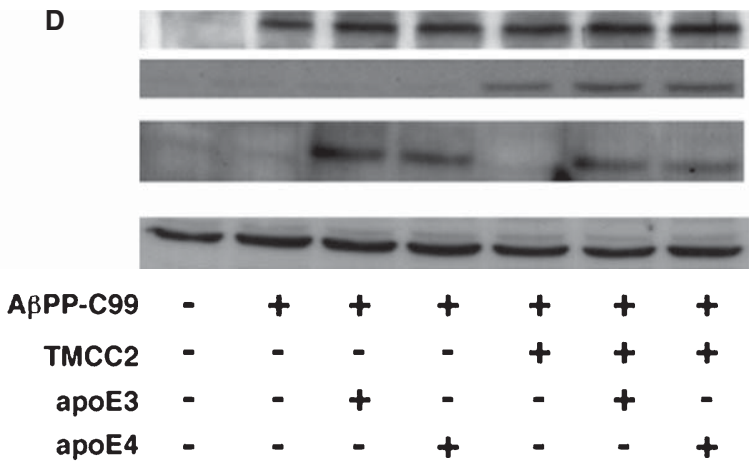

Fig. 6. A) ELISA of cell-associated A $\beta$ showing an increase in cell-associated A $\beta$ on co-expression of A $\beta P P-C 99$, apoE, and TMCC2. One-way ANOVA followed by Dunnett's comparison applied to the data for $A \beta_{1-40}$ and $A \beta_{1-42}$ separately showed a significant increase in their respective production $(P<0.05$, indicated by *). B) Detection of both soluble and oligomeric forms of A $\beta$ by denaturing urea/SDS PAGE and western blot analysis of $\mathrm{A} \beta$ produced from A $\beta \mathrm{PP}-\mathrm{C} 99$ in the presence of TMCC 2 and apoE also showed increased $\mathrm{A} \beta$ production on co-expression of apoE and TMCC2. Std represents synthetic A $\beta$ peptides of the indicated sizes; in this gel system longer species of $A \beta$ migrate further than shorter ones. C) Co-expression of TMCC2 and apoE in SHSY5Y cells increased production of both A $\beta_{1-40}$ and A $\beta_{1-42}$ from A $3 P P-C 99$. One-way ANOVA followed by Dunnett's comparison applied to the data for $A \beta_{1-40}$ and $A \beta_{1-42}$ separately showed a significant increase in their respective production $(P<0.0005$, indicated by \#\#\#). More A $\beta$ was produced when TMCC2 was co-expressed with apoE4 compared to co-expression with apoE3 $(P=0.02$, Students T-test, indicated by $*)$. D) TMCC2 and apoE do not significantly alter the steady-state levels of A $\beta P P-C 99$. SHSY5Y cells transfected with A $3 P P-C 99$ were co-transfected with apoE and TMCC 2 as indicated. The expression levels of apoE, AßPP-C99, and TMCC2 were assessed by SDS-PAGE and western blot. A blot for tubulin is included as a loading control. For (A) and (C) columns show mean values \pm SEM obtained from 3 and 7 independent experiments, respectively; $A \beta_{1-40}$ and $A \beta_{1-42}$ levels were independently normalized to the amount of $\mathrm{A} \beta$ produced in the presence of apoE3 without TMCC2.

facilitated the interaction of AßPP-C99 with $\gamma$-secretase. We found an increased apoE isoform-specific effect on $A \beta$ production as the form of $A \beta P P$ expressed progressed from wild-type $A \beta P P$ to $A \beta P P$ swe to A $\beta P P-C 99$, and an increased isoform-specific effect in the interaction between TMCC2 and apoE in vitro compared to in cells. Thus, taken together, our data suggest that TMCC2 has the ability to mediate apoEisoform-specific effects on A $\beta P P$ metabolism. Our findings further recapitulate in part previous observations that expression of apoE4 increases $\mathrm{A} \beta$ production in $A \beta P P$ swe mice compared to expression of apoE3
[17-19]. Both production of $\mathrm{A} \beta$ and apoE are associated with $\mathrm{AD}$, the interaction between apoE and TMCC 2 may therefore contribute to A $\beta P P$ metabolism in $\mathrm{AD}$.

TMCC2 is a 709 amino acid, previously unstudied, polytopic transmembrane protein almost completely conserved in sequence between rodents and humans. Apart from transmembrane and coiled-coil domains, which do not reliably predict function to any degree of specificity, TMCC2 has no identifiable functional sequence motifs, or readily identifiable functional domains. Our study therefore represents the first findings 
on this class of proteins. Currently, we can only speculate as to the molecular nature of the interaction between A $\beta P P$ and TMCC2, and how this might be further influenced by apoE. However, the simplest interpretation of our results is that, when combined, apoE and TMCC 2 facilitate an interaction between the $\mathrm{C}$-terminus of A $\beta P P$ and $\gamma$-secretase, since $\gamma$-secretase is strictly required for the production of $A \beta$. This might occur via a direct interaction between TMCC 2 and the transmembrane domain of A $\beta P P$, or alternately it could occur indirectly, possibly by modifying the interaction of $\mathrm{A} \beta \mathrm{PP}$ with one or more of its other interacting partners.

In vivo, $\mathrm{A} \beta \mathrm{PP}-\mathrm{C} 99$ is generated by $\beta$-cleavage of $\mathrm{A} \beta \mathrm{PP}$ by BACE $[10,11]$, a process that is accelerated in $A \beta P P$ swe; while most $\beta$-cleavage and generation of $\mathrm{A} \beta$ in cultured cells occurs in recycling endosomes, it may also occur in the ER compartment of certain neuronal cells [38, 39]. Pathogenic mutations in either presenilin or $A \beta P P$ favor the production of $A \beta_{1-42}$, as we observed in the presence of TMCC2 and apoE4, a finding consistent with recent studies in human postmortem tissue which found an increased concentration of intracellular $\mathrm{A} \beta$ was associated with possession of the gene for apoE4 [40].

While we found that TMCC2 and apoE lead to a significant increase in $A \beta$ production from $A \beta P P$ swe and A $\beta P P-C 99$, we did not observe a corresponding decrease in A $\beta P P-C 99$. Due in part to the compartmentalization of the various reactants, and the presence of additional interacting partners for $A \beta P P$, it is unlikely that cellular $A \beta$ production follows Michaelis-Menten kinetics. Thus, it has been found that A $\beta P P$ C-terminal fragment levels and levels of $\mathrm{A} \beta$ production are not always well correlated; some pathogenic AßPP mutations (V715A, V715 M, and $\mathrm{I} 716 \mathrm{~V})$ that increase $A \beta$ production may also paradoxically either increase C-terminal fragment levels, or have no effect [41]. Likewise, while most presenilin mutations that increase $A \beta$ production also cause a decrease in C-terminal fragment levels, others (A246E and G348A) do not [42]. Thus, increases in the rate of $\mathrm{A} \beta$ production are not necessarily reflected in directly corresponding decreases in cellular A $\beta$ PP-C99.

While we propose that the bulk of TMCC2 is in the ER, we do not exclude that it may also be present in other cell compartments. By analogy, the same "spatial paradox" exists for presenilin, most of which is present in the early secretory pathway, which is not the principal site of $A \beta$ production, at least in most cultured cell systems [43, 44]. However previous experiments were not controlled for TMCC2, and did not include
apoE, whereas in the present work we found that coexpression of apoE and TMCC2 was required for the increased production of $\mathrm{A} \beta$ observed. The location (s) of $\mathrm{A} \beta$ production in vivo is debated, primarily because it is difficult to discriminate the location of $A \beta$ production from where it is detected. Trafficking of A $\beta P P$ and its metabolic products plays a key role in the biology of $\mathrm{AD}$, and several trafficking proteins are genetically implicated in AD, such as SORL1 [45], whose loss is associated with impaired trafficking and metabolism of $A \beta P P$ and its proteolytic products $[46,47]$. In mice, isoform-specific effects of apoE on A $\beta P P$ metabolism and $A \beta$ deposition are most apparent in older individuals [17-19], and recent evidence also indicates that the isoform-specific impact of apoE in response to neurological stress is differentially and specifically affected by neuronal but not glial expression of apoE3 versus apoE4 [48]. Significant evidence indicates an important role for cellular trafficking in the metabolism of A $\beta P P$ (reviewed in [49]), therefore, age-related or pathological disruptions to the trafficking of A $\beta P P$, AßPP-C99, BACE, or TMCC2 itself, may alter the interaction of A $\beta P P-C 99$ with TMCC2, and by extension an apoE-modulated production of $A \beta$.

Our proposal that apoE can alter $A \beta$ production through its interaction with TMCC 2 does not exclude a role for apoE in the clearance or deposition of $A \beta$, either through apoE receptors, or through the bloodbrain barrier. However, residue 112, which is a Cys in apoE3 and an Arg in apoE4, is not located near the receptor binding site and, to date, there are no reports of a difference between apoE3 and apoE4 in receptor binding. Several in vitro studies have shown that both apoE3 and apoE4 may directly bind $\mathrm{A} \beta[2,22,23]$, but with uncertain conclusions as to an isoform-specific effect in this binding. However, as in other studies (discussed below) structural differences between apoE3 and apoE4 cannot be excluded as contributing to differential binding, which could be further modified by the lipidation status of apoE and the conformational or aggregation status of $A \beta$. Nevertheless, recent evidence suggests that in mice amyloid deposition is a dynamic process [50], an apoE isoform-specific increase in $\mathrm{A} \beta$ production would therefore be expected to increase the total amount of amyloid deposited, even in the presence of an isoform-independent effect of apoE on $\mathrm{A} \beta$ deposition or clearance.

In a cellular context, which is perhaps most relevant, apoE4 showed a greater impact on $A \beta$ production from A $\beta P P-C 99$ than apoE3, when combined with TMCC2. The in vitro fluorescence dequenching assays that confirmed direct binding of apoE to TMCC2 do not 
directly measure binding affinity, but rather the impact of binding on the net fluorescence of all 7 tryptophan residues in apoE when the proteins are combined. The structure of apoE is dynamic; the N-terminal domain of non-lipidated apoE, which contains the Cys112 to Arg mutation that distinguishes apoE3 from apoE4, forms a four-helix bundle [51] and differs significantly in tertiary structure from that of lipidated apoE where the bundle opens on binding lipids [52]. The domaininteraction hypothesis for the impact of the amino acid difference between apoE3 and apoE4 (Cys112 versus Arg) on the biology of apoE, which postulates that the $\mathrm{N}$-and $\mathrm{C}$-terminal domains of apoE4 are more closely associated than those of apoE3, likewise proposes an important role for structural transitions in the biology of apoE [53]. Furthermore, as apoE4 is more prone to proteolysis by a neuronal protease with chymotrypsin-like specificity than is apoE3 [54], fragments of apoE (more of which are generated from apoE4 than apoE3) may have a greater affinity for TMCC2 than full-length apoE. Additional studies are therefore required to elucidate the mechanism of binding between apoE and TMCC2 and how the Cys112 to Arg mutation that distinguishes apoE3 from apoE4 affects this.

We found that TMCC 2 and apoE only increased A $\beta$ production from cultured cells when either A $\beta P P s w e$ or A $\beta$ PP-C99 was transfected, but not from full-length wild-type A $\beta P P$. The mutation in A $\beta P P$ swe predisposes to premature cleavage of A $\beta P P$ by BACE, and A $\beta P P-C 99$ was directly transfected, and thus did not require BACE cleavage. This likely indicates that the 99-amino acid $\gamma$-secretase substrate generated by BACE cleavage of wild-type A $\beta P P$ is not significantly affected by the apoE-TMCC2 interaction, at least in the system used. Since apoE and TMCC2 together may alter the production of $A \beta$ from $A \beta P P$ swe and $A \beta P P$ C99, and TMCC2 is found in a complex with a subset of full-length A $\beta P P$ in rat brain extracts, apoE and TMCC2, or TMCC2 alone, likely also interact biologically with full-length A $\beta P P$. The biological function of $A \beta P P$ is still uncertain; proposed roles include cell adhesion, neurite outgrowth, axonal transport, apoptosis, regulation of transcription, and others (reviewed in [55]). Both apoE and A $\beta P P$ levels are increased following neurological insults such as excitotoxic stress, blunt trauma and ischemia, situations where apoE has been found to modify clinical outcomes in an isoform-specific manner [56-58]. We anticipate, therefore, that future studies on TMCC 2 may shed light on the metabolism and neurobiology of A $\beta P P$, which may be further modulated by apoE.

\section{ACKNOWLEDGMENTS}

We thank Kurt De Vos, Emma Gray, Darran Yates, Elena Ribe, Jackie Mitchell, and Christopher Miller for advice and assistance. We also thank benefactors JAH, $\mathrm{CAH}$ and JB. This work was supported by grants from the Alzheimer's Society and the Alzheimer's Research Trust awarded to PCRH.

Authors' disclosures available online (http://www.jalz.com/disclosures/view.php?id=841).

\section{REFERENCES}

[1] Corder EH, Saunders AM, Strittmatter WJ, Schmechel DE, Gaskell PC, Small GW, Roses AD, Haines JL, Pericak-Vance MA (1993) Gene dose of apolipoprotein E type 4 allele and the risk of Alzheimer's disease in late onset families. Science 261, 921-923.

[2] Strittmatter WJ, Saunders AM, Schmechel D, Pericak-Vance M, Enghild J, Salvesen GS, Roses AD (1993) Apolipoprotein E: high-avidity binding to beta-amyloid and increased frequency of type 4 allele in late-onset familial Alzheimer disease. Proc Natl Acad Sci U S A 90, 1977-1981.

[3] Raber J, Huang Y, Ashford JW (2004) ApoE genotype accounts for the vast majority of $\mathrm{AD}$ risk and $\mathrm{AD}$ pathology. Neurobiol Aging 25, 641-650.

[4] Goate A, Chartier-Harlin MC, Mullan M, Brown J, Crawford F, Fidani L, Giuffra L, Haynes A, Irving N, James L, et al (1991) Segregation of a missense mutation in the amyloid precursor protein gene with familial Alzheimer's disease. Nature. 349, 704-706.

[5] Verkkoniemi A, Somer M, Rinne JO, Myllykangas L, Crook R, Hardy J, Viitanen M, Kalimo H, Haltia M (2000) Variant Alzheimer's disease with spastic paraparesis: clinical characterization. Neurology. 54, 1103-1109.

[6] Mann DM, Pickering-Brown SM, Takeuchi A, Iwatsubo T; Members of the Familial Alzheimer's Disease Pathology Study Group (2001) Amyloid angiopathy and variability in amyloid beta deposition is determined by mutation position in presenilin-1-linked Alzheimer's disease. Am J Pathol 158, 2165-2175.

[7] Nochlin D, Bird TD, Nemens EJ, Ball MJ, Sumi SM (1998) Amyloid angiopathy in a Volga German family with Alzheimer's disease and a presenilin-2 mutation (N141I). Ann Neurol 43, 131-135.

[8] Wolfe MS, Xia W, Ostaszewski BL, Diehl TS, Kimberly WT, Selkoe DJ (1999) Two transmembrane aspartates in presenilin-1 required for presenilin endoproteolysis and gamma-secretase activity. Nature 398, 513-517.

[9] Li YM, Xu M, Lai MT, Huang Q, Castro JL, DiMuzio-Mower J, Harrison T, Lellis C, Nadin A, Neduvelil JG, Register RB, Sardana MK, Shearman MS, Smith AL, Shi XP, Yin KC, Shafer JA, Gardell SJ (2000) Photoactivated gamma-secretase inhibitors directed to the active site covalently label presenilin 1. Nature 405, 689-694.

[10] Luo Y, Bolon B, Kahn S, Bennett BD, Babu-Khan S, Denis P, Fan W, Kha H, Zhang J, Gong Y, Martin L, Louis JC, Yan Q, Richards WG, Citron M, Vassar R (2001) Mice deficient in BACE1, the Alzheimer's beta-secretase, have normal phenotype and abolished beta-amyloid generation. Nat Neurosci 4, 231-232. 
[11] Roberds SL, Anderson J, Basi G, Bienkowski MJ, Branstetter DG, Chen KS, Freedman SB, Frigon NL, Games D, Hu K, Johnson-Wood K, Kappenman KE, Kawabe TT, Kola I, Kuehn R, Lee M, Liu W, Motter R, Nichols NF, Power M, Robertson DW, Schenk D, Schoor M, Shopp GM, Shuck ME, Sinha S, Svensson KA, Tatsuno G, Tintrup H, Wijsman J, Wright S, McConlogue L (2001) BACE knockout mice are healthy despite lacking the primary beta-secretase activity in brain: implications for Alzheimer's disease therapeutics. Hum Mol Genet 10, 1317-1324.

[12] LaFerla FM, Green KN, Oddo S (2007) Intracellular amyloidbeta in Alzheimer's disease. Nat Rev Neurosci 8, 499-509.

[13] Bales KR, Verina T, Dodel RC, Du Y, Altstiel L, Bender M, Hyslop P, Johnstone EM, Little SP, Cummins DJ, Piccardo P, Ghetti B, Paul SM (1997) Lack of apolipoprotein E dramatically reduces amyloid beta-peptide deposition. Nat Genet $\mathbf{1 7}$, 263-264.

[14] Dodart JC, Bales KR, Johnstone EM, Little SP, Paul SM (2002) Apolipoprotein E alters the processing of the betaamyloid precursor protein in APP(V717F) transgenic mice. Brain Res 955, 191-199

[15] Holtzman DM, Bales KR, Wu S, Bhat P, Parsadanian M, Fagan AM, Chang LK, Sun Y, Paul SM (1999) Expression of human apolipoprotein E reduces amyloid-beta deposition in a mouse model of Alzheimer's disease. J Clin Invest $\mathbf{1 0 3}$ 2892-2897.

[16] Miao J, Vitek MP, Xu F, Previti ML, Davis J, Van Nostrand WE (2005) Reducing cerebral microvascular amyloid-beta protein deposition diminishes regional neuroinflammation in vasculotropic mutant amyloid precursor protein transgenic mice. J Neurosci 25, 6271-6277.

[17] Buttini M, Yu GQ, Shockley K, Huang Y, Jones B, Masliah E, Mallory M, Yeo T, Longo FM, Mucke L (2002) Modulation of Alzheimer-like synaptic and cholinergic deficits in transgenic mice by human apolipoprotein E depends on isoform, aging, and overexpression of amyloid beta peptides but not on plaque formation. J Neurosci 22, 10539-10548.

[18] Fryer JD, Simmons K, Parsadanian M, Bales KR, Paul SM, Sullivan PM, Holtzman DM (2005) Human apolipoprotein E4 alters the amyloid-beta 40:42 ratio and promotes the formation of cerebral amyloid angiopathy in an amyloid precursor protein transgenic model. J Neurosci 25, 2803-2810.

[19] Fagan AM, Watson M, Parsadanian M, Bales KR, Paul SM, Holtzman DM (2002) Human and murine ApoE markedly alters A beta metabolism before and after plaque formation in a mouse model of Alzheimer's disease. Neurobiol Dis $\mathbf{9}$, 305-318.

[20] Xu F, Vitek MP, Colton CA, Previti ML, Gharkholonarehe N, Davis J, Van Nostrand WE (2008) Human apolipoprotein E redistributes fibrillar amyloid deposition in Tg-SwDI mice. J Neurosci 28, 5312-5320.

[21] Irizarry MC, Deng A, Lleo A, Berezovska O, Von Arnim CA, Martin-Rehrmann M, Manelli A, LaDu MJ, Hyman BT, Rebeck GW (2004) Apolipoprotein E modulates gammasecretase cleavage of the amyloid precursor protein. $J$ Neurochem 90, 1132-1143.

[22] Sanan DA, Weisgraber KH, Russell SJ, Mahley RW, Huang D, Saunders A, Schmechel D, Wisniewski T, Frangione B, Roses AD, et al. (1994) Apolipoprotein E associates with beta amyloid peptide of Alzheimer's disease to form novel monofibrils. Isoform apoE4 associates more efficiently than apoE3. J Clin Invest 94, 860-869.

[23] LaDu MJ, Falduto MT, Manelli AM, Reardon CA, Getz GS, Frail DE (1994) Isoform-specific binding of apolipoprotein E to beta-amyloid. J Biol Chem 269, 23403-23406.
[24] DeMattos RB, Cirrito JR, Parsadanian M, May PC, O'Dell MA, Taylor JW, Harmony JA, Aronow BJ, Bales KR, Paul SM, Holtzman DM (2004) ApoE and clusterin cooperatively suppress Abeta levels and deposition: evidence that ApoE regulates extracellular Abeta metabolism in vivo. Neuron 41, 193-202.

[25] Lee EB, Zhang B, Liu K, Greenbaum EA, Doms RW, Trojanowski JQ, Lee VM (2005) BACE overexpression alters the subcellular processing of APP and inhibits Abeta deposition in vivo. J Cell Biol 168, 291-302.

[26] Ljungberg MC, Dayanandan R, Asuni A, Rupniak TH, Anderton BH, Lovestone S (2002) Neuroreport 13, 867-870.

[27] Kaether C, Schmitt S, Willem M, Haass C (2006) Amyloid precursor protein and Notch intracellular domains are generated after transport of their precursors to the cell surface. Traffic 7, 408-415.

[28] Wittig I, Braun HP, Schägger H (2006) Blue native PAGE. Nat Protoc (2006) 1, 418-428.

[29] Wiltfang J, Smirnov A, Schnierstein B, Kelemen G, Matthies U, Klafki HW, Staufenbiel M, Hüther G, Rüther E, Kornhuber J (1997) Improved electrophoretic separation and immunoblotting of beta-amyloid (A beta) peptides 1-40, 1-42, and 1-43. Electrophoresis 18, 527-532.

[30] Edbauer D, Winkler E, Haass C, Steiner H (2002) Presenilin and nicastrin regulate each other and determine amyloid betapeptide production via complex formation. Proc Natl Acad Sci U S A 99, 8666-8671.

[31] Culvenor JG, Ilaya NT, Ryan MT, Canterford L, Hoke DE, Williamson NA, McLean CA, Masters CL, Evin G (2004) Characterization of presenilin complexes from mouse and human brain using Blue Native gel electrophoresis reveals high expression in embryonic brain and minimal change in complex mobility with pathogenic presenilin mutations. Eur J Biochem 271, 375-385.

[32] Xu Q, Bernardo A, Walker D, Kanegawa T, Mahley RW, Huang Y (2006) A Profile and regulation of apolipoprotein $\mathrm{E}$ (ApoE) expression in the CNS in mice with targeting of green fluorescent protein gene to the ApoE locus. J Neurosci 26, 4985-4994.

[33] Aoki K, Uchihara T, Sanjo N, Nakamura A, Ikeda K, Tsuchiya K, Wakayama Y (2003) Increased expression of neuronal apolipoprotein $\mathrm{E}$ in human brain with cerebral infarction. Stroke 34, 875-880.

[34] Boschert U, Merlo-Pich E, Higgins G, Roses AD, Catsicas $\mathrm{S}$ (1999)Apolipoprotein E expression by neurons surviving excitotoxic stress. Neurobiol Dis 6, 508-514.

[35] Dekroon RM, Armati PJ (2001) Synthesis and processing of apolipoprotein E in human brain cultures. Glia 33, 298305.

[36] Hirose Y, Imai Y, Nakajima K, Takemoto N, Toya S, Kohsaka S. Glial (1994) conditioned medium alters the expression of amyloid precursor protein in SH-SY5Y neuroblastoma cells. Biochem Biophys Res Commun 198, 504-509.

[37] Tamboli IY, Prager K, Barth E, Heneka M, Sandhoff K, Walter $\mathrm{J}$ (2005) Inhibition of glycosphingolipid biosynthesis reduces secretion of the beta-amyloid precursor protein and amyloid beta-peptide J Biol Chem 280, 28110-28117.

[38] Chyung AS, Greenberg BD, Cook DG, Doms RW, Lee VM (1997) Novel beta-secretase cleavage of beta-amyloid precursor protein in the endoplasmic reticulum/intermediate compartment of NT2N cells. J Cell Biol 138, 671-680.

[39] Wild-Bode C, Yamazaki T, Capell A, Leimer U, Steiner H, Ihara Y, Haass C (1997) Intracellular generation and accumulation of amyloid beta-peptide terminating at amino acid 42 . J Biol Chem 272, 16085-16088. 
[40] Christensen DZ, Schneider-Axmann T, Lucassen PJ, Bayer TA, Wirths O. (2010) Accumulation of intraneuronal Abeta correlates with ApoE4 genotype. Acta Neuropathol 119, 555566.

[41] De Jonghe C, Esselens C, Kumar-Singh S, Craessaerts K, Serneels S, Checler F, Annaert W, Van Broeckhoven C, De Strooper B (2001) Pathogenic APP mutations near the gamma-secretase cleavage site differentially affect Abeta secretion and APP C-terminal fragment stability. Hum Mol Genet 10, 1665-1671.

[42] Bentahir M, Nyabi O, Verhamme J, Tolia A, Horré K, Wiltfang J, Esselmann H, De Strooper B (2006) Presenilin clinical mutations can affect gamma-secretase activity by different mechanisms $J$ Neurochem $96,732-742$.

[43] Maltese WA, Wilson S, Tan Y, Suomensaari S, Sinha S, Barbour R, McConlogue L (2001) Retention of the Alzheimer's amyloid precursor fragment C99 in the endoplasmic reticulum prevents formation of amyloid beta-peptide. J Biol Chem 276, 20267-20279.

[44] Cupers P, Bentahir M, Craessaerts K, Orlans I, Vanderstichele H, Saftig P, De Strooper B, Annaert W (2001) The discrepancy between presenilin subcellular localization and gamma-secretase processing of amyloid precursor protein J Cell Biol 154, 731-740.

[45] Rogaeva E, Meng Y, Lee JH, Gu Y, Kawarai T, Zou F, Katayama T, Baldwin CT, Cheng R, Hasegawa $\mathrm{H}$, Chen F, Shibata N, Lunetta KL, Pardossi-Piquard R, Bohm C, Wakutani Y, Cupples LA, Cuenco KT, Green RC, Pinessi L, Rainero I, Sorbi S, Bruni A, Duara R, Friedland RP, Inzelberg R, Hampe W, Bujo H, Song YQ, Andersen OM, Willnow TE, Graff-Radford N, Petersen RC, Dickson D, Der SD, Fraser PE, Schmitt-Ulms G, Younkin S, Mayeux R, Farrer LA, St George-Hyslop P (2007) The neuronal sortilin-related receptor SORL1 is genetically associated with Alzheimer disease. Nat Genet 39, 168-177.

[46] Andersen OM, Reiche J, Schmidt V, Gotthardt M, Spoelgen R, Behlke J, von Arnim CA, Breiderhoff T, Jansen P, Wu X, Bales KR, Cappai R, Masters CL, Gliemann J, Mufson EJ, Hyman BT, Paul SM, Nykjaer A, Willnow TE (2005) Neuronal sorting protein-related receptor sorLA/LR11 regulates processing of the amyloid precursor protein. Proc Natl Acad Sci U S A 102, 13461-13466.

[47] Offe K, Dodson SE, Shoemaker JT, Fritz JJ, Gearing M, Levey AI, Lah JJ (2006) The lipoprotein receptor LR11 regulates amyloid beta production and amyloid precursor protein traffic in endosomal compartments. J Neurosci 26, 1596-1603.
[48] Buttini M, Masliah E, Yu GQ, Palop JJ, Chang S, Bernardo A, Lin C, Wyss-Coray T, Huang Y, Mucke L (2010) Cellular Source of Apolipoprotein E4 Determines Neuronal Susceptibility to Excitotoxic Injury in Transgenic Mice. Am J Pathol $177,563-569$

[49] Suzuki T, Araki Y, Yamamoto T, Nakaya T (2006) Trafficking of Alzheimer's disease-related membrane proteins and its participation in disease pathogenesis. J Biochem 139, 949-955.

[50] Meyer-Luehmann M, Spires-Jones TL, Prada C, GarciaAlloza M, de Calignon A, Rozkalne A, Koenigsknecht-Talboo J, Holtzman DM, Bacskai BJ, Hyman BT (2008) Rapid appearance and local toxicity of amyloid-beta plaques in a mouse model of Alzheimer's disease. Nature 451, 720-724.

[51] Wilson C, Wardell MR, Weisgraber KH, Mahley RW, Agard DA (1991) Three-dimensional structure of the LDL receptorbinding domain of human apolipoprotein E. Science $\mathbf{2 5 2}$, 1817-1822.

[52] Peters-Libeu CA, Newhouse Y, Hatters DM, Weisgraber KH (2006) Model of biologically active apolipoprotein E bound to dipalmitoylphosphatidylcholine. J Biol Chem 281, 10731079.

[53] Mahley RW, Weisgraber KH, Huang Y (2006) Apolipoprotein E4: a causative factor and therapeutic target in neuropathology, including Alzheimer's disease. Proc Natl Acad Sci U S A 103, 5644-5651.

[54] Harris FM, Brecht WJ, Xu Q, Tesseur I, Kekonius L, Wyss-Coray T, Fish JD, Masliah E, Hopkins PC, ScearceLevie K, Weisgraber KH, Mucke L, Mahley RW, Huang Y (2003) Carboxyl-terminal-truncated apolipoprotein E4 causes Alzheimer's disease-like neurodegeneration and behavioral deficits in transgenic mice. Proc Natl Acad Sci U S A 100, 10966-10971.

[55] Zheng H, Koo EH (2006) The amyloid precursor protein: beyond amyloid. Mol Neurodegener 1, 5 .

[56] Nicoll JA, Roberts GW, Graham DI (1995) Apolipoprotein E epsilon 4 allele is associated with deposition of amyloid beta-protein following head injury. Nat. Med 1, 135-137.

[57] Slooter AJ, Tang MX, van Duijn CM, Stern Y, Ott A, Bell K, Breteler MM, Van Broeckhoven C, Tatemichi TK, Tycko B, Hofman A, Mayeux R (1997) Apolipoprotein E epsilon4 and the risk of dementia with stroke. A population-based investigation. JAMA 277, 818-821.

[58] Teasdale GM, Nicoll JA, Murray G, Fiddes M (1997) Association of apolipoprotein $\mathrm{E}$ polymorphism with outcome after head injury. Lancet 350, 1069-1071. 